\title{
Occurrence of antibodies against Neospora caninum in wild pigs (Sus scrofa) in the Pantanal, Mato Grosso do Sul, Brazil
}

\section{Ocorrência de anticorpos contra Neospora caninum em porcos-monteiro (Sus scrofa) do Pantanal, Mato Grosso do Sul, Brasil}

\author{
Herbert Sousa SOARES ${ }^{1}$; Vanessa do Nascimento RAMOS ${ }^{1}$; Carolina Fonseca OSAVA ${ }^{2}$; Solange OLIVEIRA ${ }^{1}$; \\ Matias Pablo Juan SZABÓ ${ }^{2}$; Ubiratan PIOVEZAN ${ }^{3}$; Bruno Bellopede CASTRO ${ }^{1}$; Solange Maria GENNARI ${ }^{1}$ \\ ${ }^{1}$ Universidade de São Paulo, Faculdade de Medicina Veterinária e Zootecnia, Departamento de Medicina Veterinária Preventiva e Saúde \\ Animal, São Paulo - SP, Brazil \\ ${ }^{2}$ Universidade Federal de Uberlândia, Faculdade de Medicina Veterinária, Laboratório de Ixodologia, Uberlândia - MG, Brazil \\ ${ }^{3}$ Embrapa Pantanal, Corumbá - MS, Brazil
}

\begin{abstract}
Serum samples from 83 free living wild pigs (Sus scrofa) from the Nhecolândia region, Pantanal do Mato Grosso, Brazil, were examined for the presence of antibodies against Neospora caninum by means of the indirect fluorescence antibody test (IFAT) with a cut off of 50. Antibodies were present in 10.8\%, with titers of: 1:200 in one animal, 1:400 in four and 1:800 in four. Analysis using the $\chi^{2}$ test showed an association between sex and presence of antibodies, with females showing occurrence of $20.5 \%$ and males $2.3 \%(\mathrm{p}=0.017)$. No association was found between age and occurrences of antibodies against this parasite. This was the first observation of N. caninum antibodies in Brazilian wild pigs from Pantanal.
\end{abstract}

Keywords: Sus scrofa. Neospora caninum. Pantanal. Antibodies. IFAT. Brazil.

\section{Resumo}

Amostras de soro de 83 porcos-monteiro (Sus scrofa) selvagens, oriundos da região de Nhecolândia, Pantanal do Mato Grosso, Brasil, foram examinadas para a presença de anticorpos contra Neospora caninum pela reação de imunofluorescência indireta (RIFI) com ponto de corte de 50. A ocorrência de anticorpos foi de 10,8\%, com um animal apresentando título de 1:200, quatro com 1:400 e quatro com 1:800. Quando analisados pelo teste do $\chi^{2}$, foi observada a existência de associação entre sexo e presença de anticorpos, com as fêmeas apresentando ocorrência de 20,5\% e os machos $2,3 \%$ (p = 0,017). Não houve associação entre idade e ocorrência de anticorpos contra este parasito. Esta é a primeira observação de porcos-monteiro da região do Pantanal, apresentando anticorpos contra N. caninum.

Palavras-chave: Sus scrofa. Neospora caninum. Pantanal. Anticorpos. RIFI. Brasil.

Correspondence to:

Solange Maria Gennari

Universidade de São Paulo, Faculdade de Medicina

Veterinária e Zootecnia, Departamento de Medicina

Veterinária Preventiva e Saúde Animal

Av. Prof. Orlando Marques de Paiva, 87

CEP 05508-270, São Paulo, SP, Brazil

e-mail: sgennari@usp.br

Received: 19/03/2015

Approved: 26/02/2016
Neospora caninum is an important cause of abortion among cattle worldwide. Dogs (Canis lupus familiaris), coyotes (Canis latrans), dingoes (Canis lupus dingo) and gray wolves (Canis lupus) (MCALLISTER et al., 1998; GONDIM et al., 2004; KING et al. 2010; DUBEY et al., 2011) have an important role in the epidemiology of this parasite because they are the definitive hosts, shedding the environmentally resistant oocysts in their feces. 
Neospora caninum has already been found infecting wild animals like herbivores, carnivores, rodents and marine mammals; however this parasite has only been successfully isolated from a few species (reviewed by GONDIM, 2006). The role of birds in N. caninum epidemiology is yet to be determined. Mineo et al. (2011) analyzed serum samples from 294 birds of 17 species in Brazil and none of them were seropositive for $N$. caninum, using the indirect fluorescent antibody test (IFAT $\geq 20$ ). However, using immunohistochemical techniques, $N$. caninum cysts were found in the muscle tissue of two Psittaciformes birds.

Pantanal is a huge floodplain and comprises areas of Brazil, Paraguay and Bolivia and it is one of the richest wild life areas of Brazil (ABREU et al., 2010). Wild pigs, Sus scrofa L. (Artiodactyla, Suidae), are one of the most invasive animal species worldwide (LOWE et al., 2000), and in Pantanal, wild pigs are the main hunting target, whereas the endemic species are protected by federal law and hunting is forbidden (DESBIEZ et al., 2011). Brazilian Pantanal has the country's largest wild pig population, which has become established over the last 200 years (DESBIEZ et al., 2011).

Neospora caninum antibodies in wild pigs (Sus scrofa) have been detected in the Czech Republic (BÁRTOVÁ et al., 2006), in Spain (ALMERÍA et al., 2007) and in the USA (BEVINS et al., 2013). In Pantanal region, N. caninum antibodies were detected in other species of wild animals (IFAT $\geq 1: 50$ ) as pampas-deer (Ozotoceros bezoarticus), with 75\% occurrence, 12 of 16 samples examined were positive (TIEMAN et al., 2005), and jaguars (Panthera onca), with $72.7 \%$ occurrence and 8 of 11 samples positive (ONUMA et al., 2014).

To date, no reports on seropositivity for $N$. caninum among Sus scrofa in Brazil have been published. Therefore, the purpose of this study was to survey the occurrences of antibodies against $N$. caninum in wild pigs in the Pantanal region, Brazil, where this invasive species has contact with other wild and domestic animals.

Wild pig samples were collected in Nhecolândia (1859'15's; 56 $\left.37^{\circ} 03^{\prime \prime} \mathrm{W}\right)$, a southeastern subregion of the Pantanal, state of Mato Grosso do Sul, Brazil. A detailed description of the area can be found elsewhere (RAMOS et al., 2014). The wild pigs were captured in forested areas or by water bodies using traditional local method with the aid of dogs and a lasso. After the pigs had been caught, they were sedated as described by Fontana (2011) for blood sample collection. Samples from 83 individuals were collected; serum was obtained after centrifugation; and this was identified and stored at $-20^{\circ} \mathrm{C}$ until assayed for antibodies against $N$. caninum.

The capture and handling had previously been authorized by the federal environmental authorities (SISBIO license 21416-1).

Individual serum samples were tested for the presence of IgG antibodies against $N$. caninum by means of IFAT, as previously described by Paré et al. (1995), using 1:50 dilution as the cut-off value (ALMERÍA et al., 2007; AZEVEDO et al., 2010).

The association of each qualitative variable (age and sex) with seropositivity for $N$. caninum was evaluated by means of the $\chi^{2}$ test with a significance level of 5\%. The SPSS 17 software was used to perform the analyses.

The overall occurrence rate of antibodies against $N$. caninum was $10.8 \%$, i.e. nine of the 83 animals examined were positive. The antibody titers were 200 in one animal, 400 in four, and 800 in four. In the Brazilian Pantanal area, Sus scrofa was introduced by European settlers about 200 years ago. Mourão et al. (2002) considered feral pig one important species in terms of the animal biomass it represents. Despite the low inference about the relation of this species with the native populations of fauna and other animals in the region (DESBIEZ et al., 2011), the role of this species in the epidemiological chain of diseases for humans and animals is an aspect that deserves attention (RAMOS et al., 2014). 
Table 1 presents the occurrence rate of antibodies against $N$. caninum according to age (adult versus juvenile) and sex (male versus female). Sex was a qualitative variable that presented a significant association ( $\mathrm{p}=0.017)$, such that $2.3 \%$ of males and $20.5 \%$ of females were positive.

Table 1 - Occurrences of antibodies against $N$. caninum among wild pigs (Sus scrofa) according to age and sex, in the Pantanal region, Brazil - 2015

\begin{tabular}{ccccc}
\hline & \multicolumn{3}{c}{ Number of animals } & \multirow{2}{*}{$\boldsymbol{P}$} \\
\cline { 2 - 4 } & Examined & Positive & Occurrence (\%) & \\
\hline Age & & & 11.7 & 0.729 \\
Adult & 60 & 7 & 8.7 & \multirow{2}{*}{$\mathbf{0 . 0 1 7}$} \\
Juvenile & 23 & 2 & 2.3 & \\
Gender & & & 20.5 & \\
Male & 44 & 1 & $\mathbf{1 0 . 8}$ & \\
Female & 39 & 8 & $\mathbf{9}$ & \\
Total & $\mathbf{8 3}$ & $\mathbf{9}$
\end{tabular}

The prevalence found in the present study was similar to other studies with the same animal species. Using the same technique and also the same cut-off, Almería et al. (2007) found a prevalence of $0.3 \%$ in Spain (one out of the 298 animals examined was positive). Also using IFAT and a cut-off of 40, Bártová et al. (2006) found that $18.1 \%$ of the animals were positive in the Czech Republic (102 out of the 565 animals examined). In the USA, Bevins et al. (2013) found a prevalence of $15.8 \%$, i.e. 74 out of the 467 wild pigs examined were positive for T. gondii antibodies, using a commercial ELISA kit. However, when compared with other wild animal studies in the same region (TIEMANN et al., 2005; ONUMA et al., 2014) the prevalence was lower, indicating that the wild pigs probably are less important in the epidemiology of N. caninum. Among domestic pigs, little is known about $N$. caninum infection with regard to abortion or transplacental infection. Jensen et al. (1998) experimentally infected pregnant pigs with $N$. caninum, and they observed disease caused by the parasite in the mothers and also transplacental infection. However, naturally-acquired porcine infection and disease has not been described. Helmick at al. (2002) examined serum samples from 454 breeding sows that had aborted or were considered infertile, and all of them were negative according to IFAT.

Domestic pigs in northeastern Brazil were examined for antibodies against $N$. caninum (AZEVEDO et al., 2010) and occurrence rate of 3.1\% $(4 / 130)$ was found, i.e. lower than what was observed in the present study among wild pigs using the same technique and cutoff.

$N$. caninum is a very important and prevalent parasite among cattle in Pantanal area (ANDREOTTI et al., 2004). The wild pigs of the Pantanal, including the animals of the present study, live on cattle ranches, much closer to cattle than the majority of domestic pigs. Indeed, wild pigs in the Pantanal were observed consuming bovine carcasses found in the ground (Piovezan, personal observation). This close contact probably increases the chances of infection, through wild pigs' ingestion of bovine placentae and fetal material, given that these animals are omnivorous.

In the USA, coyotes and white tailed deer (Odocoileus virginianus) are involved in the sylvatic cycle of the parasite (GONDIM, 2006). However, in South America, very little is known about the epidemiology of $N$. caninum in sylvatic environments and the role of the wild carnivores and the animals that are part of their alimentary chain. Due to the economic importance and wide biodiversity of Pantanal, more studies should be done in this region about the relationship between wild and domestic animals and $N$. caninum infection.

\section{Acknowledgements}

SM Gennari and MP Szabó have received fellowships from CNPq. We thank RA Dias for his help in the statistical analyzes. 


\section{References}

ABREU, U. G. P.; MCMANUS, C.; SANTOS, S. A. Cattle ranching, conservation and transhumance in the Brazilian Pantanal. Pastoralism, v. 1, n. 1, p. 99-114, 2010.

ALMERÍA, S.; VIDAL, D.; FERRER, D.; PABÓN, M.; FERNÁNDEZ-DE-MERA, M. I. G.; RUIZ-FONS, F.; ALZAGA, V.; MARCO, I.; CALVETE, C.; LAVIN, S.; GORTAZAR, C.; LÓPEZ-GATIUS, F.; DUBEY, J. P. Seroprevalence of Neospora caninum in non-carnivorous wildlife from Spain. Veterinary Parasitology, v. 143, n. 1, p. 21-28, 2007. doi: http://dx.doi.org/10.1016/j.vetpar.2006.07.027.

ANDREOTTI, R.; PINCKNEY, R. D.; PIRES, P. P.; SILVA, E. A. Evidence of Neospora caninum in beef cattle and dogs in the State of Mato Grosso do Sul, Center Western Region, Brazil. Revista Brasileira de Parasitologia Veterinária, v. 13, n. 3, p. 129-131, 2004.

AZEVEDO, S. S.; PENA, H. F. J.; ALVES, C. J.; GUIMARÃES FILHO, A. A. M.; OLIVEIRA, R. M.; MAKSIMOV, P.; SCHARES, G.; GENNARI, S. M. Prevalence of anti-Toxoplasma gondii and anti-Neospora caninum antibodies in swine from Northeastern Brazil. Revista Brasileira de Parasitologia Veterinária, v. 19, n. 2, p. 80-84, 2010. doi: http://dx.doi.org/10.4322/rbpv.01902002.

BÁRTOVÁ, E.; SEDLÁK, K.; LITERÁK, I. Prevalence of Toxoplasma gondii and Neospora caninum antibodies in wild boars in the Czech Republic. Veterinary Parasitology, v. 142, n. 12, p. 150-153, 2006. doi: http://dx.doi.org/10.1016/j.vetpar.2006.06.022.

BEVINS, S.; BLIZZARD, E.; BAZAN, L.; WHITLEY, P. Neospora caninum exposure in overlapping population of coyotes (Canis latrans) and feral swine (Sus scrofa). Journal of Wildlife Diseases, v. 49, n. 4, p. 1028-1032, 2013. doi: http://dx.doi.org/10.7589/201302-034.

DESBIEZ, A. L. J.; KEUROGHLIAN, A.; PIOVEZAN, U.; BODMER, R. E. Invasive species and bush meat hunting contributing to wildlife conservation: the case of feral pigs in a Neotropical wetland. Oryx, v. 45, n. 1, p. 78-83, 2011. doi: http://dx.doi.org/10.1017/S0030605310001304.

DUBEY, J. P.; JENKINS, M. C.; RAJENDRAN, C.; MISKA, K.; FERREIRA, L. R.; MARTINS, J.; KWOK, O. C. H.; CHOUDHARY, S. Gray wolf (Canis Lupus) is a natural definitive host for Neospora caninum. Veterinary Parasitology, v. 181, n. 24, p. 382-387, 2011. doi: http://dx.doi.org/10.1016/j.vetpar.2011.05.018.

FONTANA, I. Avaliação do papel do porco-monteiro na cadeia epidemiológica da leptospirose em sub-regiões do Pantanal SulMato-Grossence. 2001. 61 f. Dissertação (Mestrado em Saúde Animal) - Faculdade de Medicina Veterinária e Zootecnia, Universidade de Brasília, Brasília, 2011.
GONDIM, L. F. P. Neospora caninum in wildlife. Trends in Parasitology, v. 22, n. 6, p. 247-252, 2006. doi: http://dx.doi.org/ 10.1016/j.pt.2006.03.008.

GONDIM, L. F. P.; MCALlister, M. M.; PITT, W. C.; ZEMLICKA, D. E. Coyotes (Canis latrans) are definitive hosts of Neospora caninum. International Journal for Parasitology, v. 34, n. 2, p. 159-161, 2004. doi: http://dx.doi.org/10.1016/j.jpara.2004.01.001.

HELMICK, B.; OTTER, A.; MCGARRY, J.; BUXTON, D. Serological investigation of aborted sheep and pigs for infection by Neospora caninum. Research in Veterinary Science, v. 73, n. 2, p. 187-189, 2002. doi: http://dx.doi.org/10.1016/S0034-5288(02)00093-0.

JENSEN, L.; JENSEN, T. K.; LIND, P.; HENRIKSEN, A. S.; UGGLA, A.; BILLE-HANSEN, V. Experimental porcine neosporosis. APMI, v. 106, n. 1-6, p. 475-482, 1998. doi: http://dx.doi.org/10.1111/j.1699-0463.1998.tb01374.x.

KING, J. S.; SLAPETA, J.; JENKINS, D. J.; AL-QASSAB, S. E.; ELLIS, J. T.; WINDSOR, P. A. Australian dingoes are definitive hosts of Neospora caninum. International Journal for Parasitology, v. 40, n. 8, p. 945-950, 2010. doi: http://dx.doi.org/10.1016/j.ijpara.2010.01.008.

LOWE, S.; BROWNE, M.; BOUDJELAS, D.; DEPOORTER, M. 100 of the world's worst invasive alien species: a selection from the global invasive species database. Auckland: Invasive Species Specialist Group, 2000. 12 p.

MCALLISTER, M. M.; DUBEY, J. P.; LINDSAY, D. S.; JOLLEY, W. R.; WILLS, R. A.; MCGUIRE, A. M. Dogs are definitive hosts of Neospora caninum. International Journal for Parasitology, v. 28, n. 9, p. 1473-1478, 1998. doi: http://dx.doi.org/10.1016/S00207519(98)00138-6.

MINEO, T. W. P.; CARRASCO, A. O. T.; RASO, T. F.; WERTHER, K.; PINTO, A. A.; MACHADO, R. Z. Survey for natural Neospora caninum infection in wild and captive birds. Veterinary Parasitology, v. 182, n. 2-4, p. 352-355, 2011. doi: http://dx.doi.org/10.1016/j.vetpar.2011.05.022.

MOURÃO, G. M.; COUTINHO, M. E.; MAURO, R. A.; TOMÁS, W. M.; MAGNUSSON, W. Levantamentos aéreos de espécies introduzidas no Pantanal: porcos ferais (porco-monteiro), gado bovino e búfalos. Boletim de Pesquisa e Desenvolvimento, n. 28, p. 1-22, 2002.

ONUMA, S. S. M.; MELO, A. L. T.; KANTEK, D. L. Z.; CRAWSHAW-JUNIOR, P. G.; MORATO, R. G.; MAY-JÚNIOR, J. A.; PACHECO, T. A.; AGUIAR, D. M. Exposure of free-living jaguars to Toxoplasma gondii, Neospora caninum and Sarcocystis neurona in the Brazilian Pantanal. Revista Brasileira de Parasitologia Veterinária, v. 23, n. 4, p. 547-553, 2014. doi: http://dx.doi.org/10.1590/S1984-29612014077. 
PARÉ, J.; HIETALA, S. K.; THURMOND, M. C. Interpretation of an indirect fluorescent antibody test for diagnosis of Neospora sp. Infection in cattle. Journal of Veterinary Diagnostic Investigation, v. 7, n. 2, p. 273-275, 1995 doi: http://dx.doi.org/10.1177/104063879500700222.

RAMOS, V. N.; PIOVEZAN, U.; FRANCO, A. H. A.; OSAVA, C. F.; HERRERA, H. M.; SZABÓ, M. P. J. Feral pigs as hosts for Amblyomma sculptum (Acari: Ixodidae) populations in the Pantanal, Mato Grosso do Sul, Brazil. Experimental and Applied Acarology, v. 64, n. 3, p. 393-406, 2014. doi: http://dx.doi.org/10.1007/s10493-014-9832-9.

TIEMANN, J. C. H.; SOUZA, S. L. P.; RODRIGUES, A. A. R.; DUARTE, J. M. B.; GENNARI, S. M. Environmental effect on the occurrence of anti-Neospora caninum antibodies in pampas-deer (Ozotoceros bezoarticus). Veterinary Parasitology, v. 134, n. 1-2, p. 73-76, 2005. doi: http://dx.doi.org/10.1016/j.vetpar.2005.07.015. 